\title{
ANALISIS KINERJA APARATUR PELAYANAN PUBLIK DALAM PENGURUSAN DAN PENERBITAN IZIN MENDIRIKAN BANGUNAN PADA DPMPTSP KABUPATEN BULUKUMBA
}

\author{
Performance Analysis of Public Service Apparatus in The Management and Issuance of Building \\ Permits in DPMPTSP of Bulukumba Regency
}

\author{
Subarling $^{1}$, Andi Rasyid Pananrangi ${ }^{2}$, Syamsul Bahri \\ ${ }^{1}$ Dinas Penanaman Modal dan Pelayanan Terpadu Satu Pintu Kabupaten Bulukumba \\ ${ }^{2}$ Program Studi Ilmu Administrasi Negara Program Pascasarjana Universitas Bosowa
}

Email: subarlingblk@gmail.com

Diterima: 07 Februari 2020

Dipublikasikan: 05 Juni 2020

\begin{abstract}
ABSTRAK
Penelitian ini bertujuan untuk menganalisis dan menginterpertasi peningkatan mutu pelayanan perizinan khususnya pemberian izin mendirikan bangunan di Kab.Bulukumba. Penelitian ini bersifat deskriptif dengan menggunakan pendekatan kualitatif dimana data diperoleh dari sejumlah informan baik pemberi layanan (Petugas) maupun penerima layanan (Masyarakat). Hasil penelitian mengenai kinerja aparatur pelayanan yang diterapkan pada Dinas Penanaman Modal dan Pelayanan Terpadu Satu Pintu Kabupaten Bulukumba menunjukkan kinerja aparatur pelayanan Aparatur Pelayanan Dinas Penanaman Modal dan Pelayanan Terpadu Satu Pintu Kabupaten Bulukumba terkait sikap dan perilaku dalam memberikan pelayanan kepada masyarakat di Kabupaten Bulukumba atas pengurusan dan penerbitan Izin Mendirikan Bangunan Pelaksananaannya telah baik namum belum sempurna dan perlu di tingkatkan lagi.
\end{abstract}

Kata Kunci: Analisis Kinerja, Pelayanan, Pembangunan, IMB, Bulukumba

\section{ABSTRACT}

Study aims to analyze and interpret the improvement of the quality of licensing services, especially granting building permits in the Regency of Bulukumba. This research is descriptive using a qualitative approach in which data is obtained from a number of informants, both service providers (officers) and service recipients (community). The results of the research regarding the performance of the public service apparatus applied at the Investment and One-Stop Integrated Services Office of Bulukumba Regency shows that the performance of the public service apparatus of the Investment and One-Stop Integrated Services Office of Bulukumba Regency related to attitudes and behavior in providing services to the community in Bulukumba Regency for the management and issuance of Building Permits for the implementation has been good but not yet perfect and needs to be improved.

Keywords: Performance Analysis, Service, Building, Building Permits, Bulukumba

\section{PENDAHULUAN}

Pemerintahan yang baik (good governance) sebagai bagian dari agenda reformasi dengan tujuan agar terciptanya pemerintahan yang baik dan bersih (good clean governance), meliputi profesionalitas, akuntabilitas, transparansi, pelayanan prima, demokrasi dan partisipasi, efesiensi dan efektivitas, supermasi hukum, bervisi strategis. Tjokromidjoj dalam Sinambela (2006) dan United Nation Development Program (UNDP) dalam Mardiasmo (2004). (Nubatonis et al., 2014). Dengan diterapkannya otonomi daerah melalui Undang-undang nomor 32 tahun 2004 tentang Pemerintahan Daerah, maka pengaturan rumah tangga daerah diserahkan pada daerah yang bersangkutan. Dalam kaitannya dengan pelaksanaan fungsi pemerintahan, upaya peningkatan pelayanan oleh pemerintah mulai diujudkan dalam bentuk penerapan prinsip-prinsip good governance (tata pemerintahan yang baik). Melalui Pemberlakuan otonomi daerah diharapkan daerah dapat bersaing dan meningkatkan kualitas pembangunan dengan memperhatikan asas demokrasi, pemerataan, keadilan, keistimewaan dan keanekaragaman serta potensi daerah dalam sistem Negera Kesatuan Republik Indonesia/ NKRI (UU No 32 tahun 2004)

Dibidang penyelenggaraan pemerintahan, isu yang disuarakan adalah persoalan pelayanan publik oleh organisasi publik atau organisasi pemerintah. Selama ini ada kesan pelayanan oleh petugas dalam organisasi pemerintah belum memuskan seperti yang diharapkan, berbagai isu mucul diantaranya adalah bahwa pelayanan bersifat pilih kasih, mengandung unsur $\mathrm{KKN}$, berbelitbelit, dan tidak merugikan masyarakat, untuk itu perlunya peningkatan dan perbaikan sistem pelayanan kepada masyarakat menjadi sesuatu yang penting dan hal yang tak terelakkan, sebagaimana yang kita ketahui tujuan utama sektor publik adalah pemberian pelayanan 
publik (public service) bukan untuk memaksimumkan laba (Azlina \& Amelia, 2015).

Pelayanan publik yang dilaksanakan oleh aparatur pemerintah dalam melayani masyarakat merupakan implikasi dari fungsi aparatur negara sebagai pelayan masyarakat dimana penyelengggaraan tugas dan pokok serta fungsi sebagai aparatur sipil negara (ASN) dan sebagai aparat pemerintah dalam memberikan pelayanan kepada masyarakat dituntut agar berkinerja yang baik sehingga pelayanan yang diberikan dapat berkwalitas. Tugas utama aparatur sipil negara (ASN) sebagai aparatur pemerintah adalah untuk memberikan pelayanan terbaik kepada masyarakat, pelayanan yang diberikan individu aparatur merupakan cerminkan kinerja individu yang akan menentukan baik atau buruknya kinerja secara keseluruhan sebuah organisasi. Menurut keban (dalam Ariany \& Putera, 2013) Kinerja (performance) dapat didefinisikan sebagai tingkat pencapaian hasil atau degree of accomplishment atau dengan kata lain, kinerja merupakan tingkat pencapaian tujuan organisasi, sejalan dengan pendapat Rogers yang dikutip Mahmudi (dalam Ariany \& Putera, 2013) yang menyebutkan bahwa kinerja didefinisikan sebagai hasil kerja itu sendiri (outcomes of work), karena hasil kerja memberikan keterkaitan yang kuat terhadap tujuantujuan strategic organisasi, kepuasan pelanggan, dan kontribusi ekonomi.

Dalam konteks pelayanan publik pelayanan yang diberikan oleh aparatur pelayanan adalah mempermudah urusan publik dengan memberikan pelayanan yang tidak berbelit-belit dan prosedur yang panjang, lebih mendahulukan kepentingan umum daripada kepentingan pribadi, mempersingkat waktu pelaksanaan pelayanan publik serta memberikan kepuasan kepada masyarakat sebagai penerima layanan. Pelayanan publik pada dasarnya adalah memberikan pelayanan terbaik kepada masyarakat yang merupakan perwujudan dari pelaksanaan kewajiban seorang aparatur negara sebagai abdi masyarakat.

Kewajiban negara dalam rangka pemenuhan pelayanan kepada masyarakat diatur dalam Undangundang Republik Indonesia Nomor 25 Tahun 2009 tentang Pelayanan Publik. Sebagai percepatan dalam pembenahan pelayanan yang ada di bentuklah Pelayanan Terpadu Satu Pintu yang merupakan pelayanan secara terintegrasi dalam satu kesatuan proses dimulai dari tahapan permohonan sampai dengan tahap penyelesaian produk pelayanan melalui satu pintu, untuk itu diperlukan adanya sumber daya aparatur yang tanggap terhadap pemenuhan kebutuhan masyarakat akan pelayanan publik, memiliki kemampuan dan keterampilan yang memadai, bersikap ramah dan cekatan.

Penyelenggara Pelayanan Terpadu Satu Pintu diselenggarakan sampai ke tingkat propinsi dan kabupaten dimana dalam menyelenggarakan pelayanan terpadu satu pintu oleh kabupaten/kota dilaksanakan oleh dinas/badan/kantor yang diberikan pendelegasian kewenangan perizinan dan non perizinan yang menjadi urusan pemerintah kabupaten/kota kepada kepala dinas/badan/kantor yang menyelenggarakan pelayanan terpadu satu pintu seperti tertuang dalam Peraturan Presiden Republik Indonesia Nomor 97 Tahun 2014 tentang Penyelenggaraan Pelayanan Terpadu Satu Pintu dan Penanaman Modal. Penyelenggaraan pelayanan terpadu satu pintu dilaksanakan dalam rangka mendekatkan dan meningkatkan pelayanan kepada masyarakat serta memperpendek proses pelayanan guna mewujudkan pelayanan yang cepat, murah, transparan pasti dan terjangkau.

Penelitian ini bertujuan untuk menganalisis dan menginterpertasi dalam meningkatkan mutu pelayanan perizinan khususnya pemberian izin mendirikan bangunan di Kab.Bulukumba.

\section{METODE}

Penelitian dilaksanakan di Kantor Dinas Penanaman Modal dan Pelayanan Terpadu Satu Pintu Kabupaten Bulukumba. Informan sebanayak 14 orang, dengan menggunakan dua sumber data yaitu data primer dan data sekunder. Teknik pengumpulan data digunakan dengan metode wawancara, observasi, dan dokumentasi.

Jenis penelitian berupa penelitian deskriptif kualitatif yang dimaksudkan untuk eksplorasi dan klarifikasi mengenai suatu kenyataan sosial dengan cara mendeskripsikan sejumlah variabel berkenaan dengan masalah unit yang diteliti.

\section{HASIL DAN PEMBAHASAN}

Kabupaten Bulukumba pada tahun 2018 telah mulai menyelenggarakan pelayanan terpadu satu pintu. Badan Pelayanan Terpadu Satu Pintu dan Penanaman Modal Kabupaten Bulukumba sebagai pelaksana pemerintah daerah di bidang Penanaman Modal dan Perizinan melaksanakan tugas dibidang Pelayanan Terpadu Satu Pintu dan Penanaman Modal berdasarkan peraturan perundang-undangan yang berlaku. Jenis perizinan yang dikelola oleh Dinas Penanaman Modal dan Pelayanan Terpadu Satu Pintu Kabupaten Bulukumba sebanyak 24 jenis perizinan yang dimana salah satunya adalah Izin Mendirikan Bangunan sesuai dengan Peraturan Bupati Nomor 49 tahun 2017

Sebagai daerah yang sedang berkembang Kabupaten Bulukumba memerlukan penataan wilayah dan perumahan Potensi investasi dan ketersediaan sumber daya alam dan jumlah penduduk yang cukup banyak di Kabupaten Bulukumba memberikan peluang dan potensi investasi kepada investor untuk menanamkan modalnya guna berinvestasi di Kabupaten Bulukumba dimana akan melakukan Pengurusan beberapa izin diantaranya Izin Mendirikan Bangunan. Izin yang dikelola Dinas Penanaman Modal dan Pelayanan Terpadu Satu pintu Kabupaten Bulukumba cukup banyak dan bervariasi akan tetapi yang menjadi sumber Pendapatan Asli Daerah yaitu dari Retribusi Izin Mendirikan Bangunan. Izin Mendirikan Bangunan telah memiliki Standar 
Operasional Prosedur dalam pelaksanaannya. Diatur melalui Peraturan Daerah kabupaten Bulukumba Nomor 16 Tahun 2012 Tentang Retribusi Izin Mendirikan Bangunan (IMB), sehingga penulis memfokuskan penelitian ini pada Pelayanan Izin Mendirikan Bangunan

Pelaksanaan urusan perizinan dibutuhkan adanya sumber daya aparatur pelayanan yang memiliki kinerja yang baik, mampu melayani masyarakat dengan ramah, memiliki pengetahuan dan kompetensi dibidangnya adanya sarana dan prasarana yang memadai, prosedur dan biaya jelas dan transparan waktu yang dibutuhkan dalam menyelesaikan perizinan tidak terlalu lama. Prioritas pembangunan di Kabupaten Bulukumba salah satunya yaitu peningkatan kerjasama dan tata kelola pemerintahan yang baik melalui optimalisasi pelayanan publik sesuai Standar Pelayanan Minimal dan Standar Operasional Prosedur.

\section{Kinerja Pelayanan Publik di DPMPTSP Kabupaten Bulukumba}

Penerbitan/ Pemberian Izin Mendirikan Bangunan (IMB) di Kabupaten Bulukumba diatur dengan Peraturan Daerah No.16 Tahun 2012 tentang Retribusi Izin Mendirikan Bangunan dimana mengatur tentang besaran biaya pengurusan Izin Mendirikan Bangunan perjenis bangunan, serta Peraturan Bupati Bulukumba No.49 Tahun 2017 tentang Perubahan Atas Peraturan Bupati Nomor 88 Tahun 2015 Tentang Penyelenggaraan Perizinan dan Non Perizinan Terpadu Satu Pintu Pemerintah Kabupaten Bulukumba yang mengatur persyaratan dan dokumen kelengkapan didalam melakukan pengurusan IMByang ditindak lanjuti dengan Standar Operasional Prosedur yang dikeluarkan oleh Dinas Penanaman Modal dan Pelayanan Terpadu Satu Pintu Kabupaten Bulukumba terkait Izin Mendirikan Bangunan.Sesuai data yang penulis terima jumlah penerbitan Izin Mendirkan Bangunan (IMB) pada 3 (tiga) tahun terakhir dapat kita liat pada tabel berikut:

Tabel 1 Jumlah Penerbitan IMB

\begin{tabular}{cccc}
\hline No & Tahun & \multicolumn{2}{c}{ Jumlah Penerbitan IMB } \\
\hline 1 & 2017 & 750 & Izin \\
2 & 2018 & 1.617 & Izin \\
3 & 2019/ Oktober & 1.877 & Izin \\
\hline & Jumlah & \multicolumn{2}{c}{4.244} \\
\hline
\end{tabular}

Sumber: DPMPTSP Kabupaten Bulukumba 2019

Tabel 1 diatas dapat dilihat peningkatan pengurusan/ penerbitan izin mendirikan bangunan meningkat terlihat dari jumlah penerbitan izin medirikan bangunan di Kabupaten Bulukumba mengalami peningkatan setiap tahunnya.

Hasil penelitian menunjukkan gambaran proses layanan perizinan dilokasi penelitian:

\section{Kemudahan Prosedur}

Kemudahan prosedur penerbitan Izin Mendirikan Bangunan pada Dinas Penanaman Modal dan Pelayanan Terpadu Satu Pintu Kabupaten Bulukumba masih belum baik karena masih dianggap terlalu rumit terbukti dari kasil Observasi ketidak jelasan nilai pembayaran IMB yang tidak secara transparan digambarkan kepada pemohon, hal ini tidak sejalan dengan KepmenPAN No.63/KEP/M.PAN/7/2003 tentang Pedoman Umum Penyelenggaraan Pelayanan Publik, yaitu Prosedur pelayanan tidak berbelit-belit dan mudah dipahami Prosedur pelayanan merupakan salah satu dari standar pelayanan publik. Prosedur pelayanan harus dibakukan bagi pemberi dan penerima pelayanan publik, termasuk pengaduan sehingga tidak terjadi permasalahan dikemudian hari. Prosedur pelayanan harus ditetapkan melalui standar operasional prosedur, sehingga pihak penerima pelayanan dapat memahami mekanismenya. Prosedur pelayanan tidak berbelit-belit dan mudah dipahami serta Produk pelayanan yang dihasilkan dari pelayanan akan diterima masyarakat sesuai dengan ketentuan yang telah ditetapkan. Biaya pelayanan termasuk rinciannya harus ditentukan secara konsisten dan tidak boleh ada diskriminasi, sebab akan menimbulkan ketidakpercayaan penerima pelayanan kepada pemberi pelayanan. Biaya pelayanan ini harus jelas pada setiap jasa pelayanan yang akan diberikan kepada masyarakat, sehingga tidak menimbulkan kecemasan, khususnya kepada pihak atau masyarakat yang kurang mampu.

\section{Kecepatan Penerbitan IMB}

Kecepatan penerbitan IMB pada Dinas Penanaman Modal dan Pelayanan Terpadu Satu Pintu Kab. Bulukumba sudah dianggap baik, adapun keterlambatan penerbitan itu diakibatkan oleh hal lain diluar kewenangan dari Dinas Penanaman Modal dan pelayanan Terpadu Satu Pintu Kabupaten Bulukumba dan merupakan wewenan dari OPD/ Instansi teknis terkait dengan waktu penerbitan rekmendasi teknis, hal ini sejalan Menurut Malayu S.P. Hasibuan (2001: 34) mengemukakan bahwa:

"Kinerja (prestasi kerja) adalah suatu hasil kerja yang dicapai seseorang dalam melaksanakan tugas-tugas yang dibebankan kepadanya yang didasarkan atas kecakapan, pengalaman dan kesungguhan serta waktu”.

\section{Ketepatan Penerbitan IMB}

Pendirian bangunan di Kabupaten Bulukumba kadangkala sudah tidak sejalan dengan dokumen perizinan IMB yang mereka miliki hal ini diakibatkan karena hasil pembangunan kadangkala dirubah fungsi setelah bangunan tersebut selesai dibangun, seperti dapat digambarkan pada bangunan yang difungsikan sebagai bangunan usaha burung walet yang marak di Kabupaten Bulukumba saat ini, yang pada awal pembangunan pemilik bermohon IMB sebagai bangunan Ruko dengan alasan dijadikan rumah tinggal dan tempat usaha toko, namun pada kenyataannya setelah selesai dibangun bangunan tersebut dialih fungsikan sebagai sarang burung walet dimana untuk bangunan Sarang burung walet tersebut belom dapat diberikan IMB diakibatkan karena jenis bangunan walet belum tercantum di PERDA IMB sehingga banyak masyarakat menempuh jalan sebagaimana diatas demi membangunan sarang burung walet, hal tersebut tidak sesuai lagi dengan dokumen 
perizinan IMB yang mereka miliki yang pada kenyataan awalnya saat IMB akan diterbitkan telah dilkukan survei oleh tim teknis terkait, ini bukan merupakan ketidak tepatan penerbitan IMB di Bulukumba yang dilakukan oleh Dinas Penanaman Modal dan Pelayanan Terpadu Satu Pintu Kabupaten Bulukumba, tetapi ini merupakan ketidak sadaran masyarakat didalam melakukan kegiatan terkait bangunan yang tidak sesuai peruntukannya.

\section{Sikap dan Pelayanan Petugas}

Sikap dan Pelayanan Petugas Dinas Penanaman Modal dan Pelayanan Terpadu Satu Pintu Kabupaten Bulukumba sudah dianggap baik terbukti dengan adanya beberapa penghargaan yang di dapatkan antara lain nilai Indeks Survey Kepuasan Masyarakat pada aspek penilaian Sikap Perilaku Petugas Pelayanan dalam tahun 2017 dan tahun 2018 yang mendapat nilai "sangat baik" serta penilaian Sistem Informasi Pelayanan Publik oleh Kementerian Pendayagunaan Aparatur dan Reformasi Birokrasi (MenpanRB) dengan mendapatkan piagam penghargaan pada tanggal 5 November 2019 sebagai role model pelayanan publik kategori "baik dengan catatan", hal ini sejalan dengan pendapat Anwar Prabu Mangkunegara (2000: 67) : Kinerja (prestasi kerja) adalah hasil kerja secara kualitas dan kuantitas yang dicapai oleh seseorang pegawai dalam melaksanakan tugasnya sesuai dengan tanggung jawab yang diberikan kepadanya”.

Peningkatan nilai hasil Indeks Survey Kepuasan Masyarakat pada aspek penilaian Sikap Perilaku Petugas Pelayanan dalam tahun 2017 dan tahun 2018 yang mendapat nilai "sangat baik" serta penilaian Sistem Informasi Pelayanan Publik oleh Kementerian Pendayagunaan Aparatur dan Reformasi Birokrasi (MenpanRB) diatas merupakan bukti kepercayaan masyarakat terhadap kesadaran aparat pelayanan atas pengurusan izin di Kabupaten Bulukumba yang menyadari bahwa tugas pelayanan yaitu membantu menyediakan serta mengurusi dan menyiapkan apa yang diperlukan dan dibutuhkan oleh masyarakat baik berupa barang atau jasa dilakukan dengan sebaik-baiknya sesuai dengan ketentuan yang berlaku dimana produk barang atau jasa yang dihasilkan dapat dinikmati masyarakat melalui sikap kerja aparatur yang ramah dan baik sehingga masyarakat akan merasa puas dengan pelayanan tersebut yang akan menumbuhkan kepercayaan masyarakat terhadap pemerintah.

\section{Kenyamanan Pengurusan}

Kenyamanan sarana dan prasarana disaat melakukan pengurusan perizinan di Kantor Dinas Penanaman Modal dan Pelayanan Terpadu Satu Pintu Kabupaten Bulukumba belum terlalu baik, hal ini terbukti dengan kurangnya sarana prasarana pendukung pelayanan yang memadai seperti WA, Toilet dll. Hal ini diakibatkan oleh keterbatasan dana pemeliharaan dan dana operasional di Kabupaten Bulukumba.

\section{Indikator Yang Mempengaruhi Kinerja Pelayanan}

Penerbitan Dokumen Izin Mendirikan Bangunan di Kabupaten Bulukumba sangat dipengaruhi oleh beberapa indikator, baik dari segi kecepatan waktu penerbitan, ketepatan penerbitan dan prosedur maupun sampai dengan tingkat keluhan masyarakat atas hasil output dari Dokumen IMB yang telah dikeluarkan serta sarana dan prasarana ruang pelayanan Kantor Dinas Penanaman Modal dan Pelayanan Terpadu Satu pintu Kabupaten Bulukumba di uraikan sebagai berikut:

a. Tingkat Kesadaran Masyarakat.

Tingkat kesadaran masyarakat Kabupaten Bulukumba dianggap masih kurang dari nilai memadai kaitannya dengan pengurusan Izin Mendirikan Bangunan, terbukti dengan masih banyaknya penulis temukan bangunan-bangunan yang didirikan secara permanen maupun direnovasi namun tidak memiliki Izin Mendirikan Bangunan, yang seharusnya Sebelum mendirikan bangunan wajib mengajukan permohonan IMB disamping itu banyak bangunan yang didirikan tidak memenuhi syarat atas garis sempadan jalan yang dimana seharusnya pemilik lahan harus mengetahui garis sempadan atas lokasi bangunan tersebut yang mengatur antara jarak bangunan dengan jalan/ laut/ maupun sungai, namun pada umumnya para pemilik bangunan mengabaikan dengan alasan tidak menyadari dan tidak memahami keberadaan garis sempadan, Hal ini seharusnya bisa dihindari atas kesadaran masyarakat dalam membangun dan setiap kali melakukan perubahan atas bangunan yang dimiliki maka pemilik bangunan seharusnya melakukan perubahan atas IMB yang dimiliki sehingga akan mendapat informasi atas ketentuan garis sempadan yang berlaku.

Pelanggaran juga sering dilakukan oleh pemilik bangunan liar yang tentunya tidak memiliki IMB dan tidak mengakses informasi mengenai garis sempadan ini, disamping itu menurut pemaparan Tim Teknis Dinas Perumahan Pemukiman dan Pertanahan (di atas) bahwa kendala peninjauan lapangan itu masih sering ditemui bahwa adanya perbedaan antara dokumen permohonan dengan lokasi tempat bangunan akan dibangun, adanya perbedaan ukuran bangunan yang ada pada permohonan dengan bangunan yang akan dibangun, hal ini berkaitan dengan besaran pembayaran retribusi Izin Mendirikan Bangunan yang tolak ukur perhitungannya berdasarkan ukuran luas bangunan dengan berpatokan kepada indeks luas bangunan, jenis bangunan, serta tempat dan lokasi bangunan yang akan dibangun sehingga masayarakat membuat pengurangan ukuran besaran bangunan pada permohonan izin demi untuk memanipulasi dan memperkecil jumlah nominal pembayaran Izin Mendirikan Bangunan.

Banyaknya bangunan yang didirikan terlalu dekat dengan jalan raya yang sesuai dengan ketentuan bahwa bangunan yang akan didirikan harus berdasarkan kepada Sempadan Bangunan dimana Garis Sempadan Bangunan (GSB) adalah garis batas pekarangan terdepan terhadap tepi jalan yang mempunyai jarak tertentu dari jalan, ini juga membuktikan bahwa tingkat kesadaran masyarakat Kabupaten Bulukumba masih rendah karena semata mata demi membangun untuk kepentingan pribadi tetapi 
mengabaikan ketentuan aturan, keindahan, serta mengabaikan keselamatan orng lain.

b. Lokasi Serta Kondisi Lahan/Bangunan Pemohon.

Kabupaten Bulukumba yang kawasannya terdiri dari daratan rendah, pantai dan laut lepas, daerah dataran rendah dengan ketinggian antara $0 \mathrm{~s} / \mathrm{d} 25$ meter di atas permukaan laut dan daerah perbukitan di Kabupaten Bulukumba terbentang mulai dari Barat ke utara dengan ketinggian $100 \mathrm{~s} / \mathrm{d}$ di atas 500 meter dari permukaan laut dimana mayoritas penduduknya menempati/ memilih daerah daerah pesisir sebagai tempat tinggal sehubungan dengan aktifitas mereka yang didominasi nelayan.

Maraknya bangunan bangunan yang didirikan tidak sesuai dengan ketentuan karena didirikan berdekatan dengan garis pantai, hal tersebut menyebabkan kendala didalam menerbitkan Izin Mendirikan Bangunan karena sesuai dengan ketentuan bahwa minimal 100 (seratus) meter dari titik pasang tertinggi ke arah darat. Garis batas ini adalah bagian dari usaha pengamanan pantai yang bertujuan untuk melindungi masyarakat dari bahaya gelombang air laut pasang tinggi (rob), melindungi dari abrasi, menjaga pantai dari pencemaran, serta pendangkalan muara sungai, namun hal ini tidak meyurutkan niat sebahagian masyarakat Kabupaten Bulukumba untuk mendirikan bangunan tanpa menghiraukan batas nilai senpadan pantai disebabkan karena lokasi/ tanah tersebut telah bersertifikat dan alasan mereka yang paling mendasar bahwa mereka hanya memiliki tanah tersebut satu satunya sehingga menyulitkan mereka untuk mendirikan bangunan ditempat lain.

Dari hal tersebut diatas menjadi salah satu kendala yang dihadapi oleh Dinas Penanaman Modal dan Pelayanan Terpadu Satu Pintu untuk memberikan pelayanan terbaik kepada masyarakat karena dengan ketidaksesuaian lokasi bangunan yang dimohonkan Izin Mendirikan Bangunan dengan aturan batas Sempadan maka dengan secara otomatis dinyatakan bahwa lokasi tersebut tidak layak untuk diberikan Izin Mendirikan Bangunan sesuai dengan pertimbangan penolakan oleh Tim Teknik Dinas Perumahan Pemukiman dan Pertanahan yang telah melakukan peninjauan/ verifikasi berkas dan lokasi permohonan di lapangan.

\section{c. Alokasi Anggaran}

Alokasi Anggaran yang dimaksudkan penulis sebagai salah satu indikator penghambat pelaksanaan pelayanan terbaik pada Dinas Penanaman Modal dan Pelayanan Terpadu Satu Pintu kabupaten Bulukumba iyalah pemberian anggaran dalam rangka pemenuhan sarana dan prasana Dinas Penanaman Modal dan Pelayanan Terpadu Satu Pintu yang di khususkan untuk pelaksanaan pemberian kenyamanan kepada masyarakat luas/ publik disaat melakukan pengurusan izin, seperti contonya tersedianya fasilitas Toilet yang memadai, terciptanya ruang tunggu pelayanan yang menyenangkan dan sejuk, serta adanya sarana transportasi untuk Tim Teknis yang memadai sehingga memudahkan pelaksanaan peninjauan, verifikasi lokasi serta pengawasan atas pelaksanaan pembangunan secara cepat di Kabupaten Bulukumba oleh Dinas Penanaman Modal dan Pelayanan Satu Pintu Kabupaten Bulukumba.

d. Regulasi/ Ketentuan.

Ketentuan/ Aturan mengenai Penerbitan/ Pemberian Izin Mendirikan Bangunan (IMB) di Kabupaten Bulukumba diatur dengan Peraturan Daerah No.16 Tahun 2012 tentang Retribusi Izin Mendirikan Bangunan, namun peraturan tersebut dianggap sudah tidak relevan lagi dengan perkembangan saat ini karena sudah berumur kurang lebih 8 tahun, hal ini terbukti dengan adanya beberpa jenis bangunan yang marak di bangun saat ini belom tertuang didalam Peraturan Daerah ini seperti contohnya pembangunan bangunan walet yang belum tertuang didalam peraturan ini. Hal tersebut sangat mempengaruhi kwalitas pemberian layanan kepada masyarakat oleh Dinas Penanaman Modal dan Pelayanan Terpadu Satu Pintu Kabupaten Bulukumba, karena menyebabkan beberapa ketimpangan didalam memberikan suatu keputusan atas suatu lokasi/ suatu bangunan yang belom tercantum didalam Peraturan Daerah yang mengatur tentang Izin Mendirikan Bangunan di kabupaten Bulukumba.

\section{KESIMPULAN}

Hasil penelitian dapat ditarik kesimpulan bahwa kinerja Aparatur Pelayanan Dinas Penanaman Modal dan Pelayanan Terpadu Kabupaten Bulukumba terkait sikap dan perilaku dalam memberikan pelayanan kepada masyarakat di kabupaten Bulukumba atas pengurusan dan penerbitan Izin Mendirikan Bangunan Pelaksananaannya telah baik dalam memberikan pelayanan kepada masyarakat di Kabupaten Bulukumba atas pengurusan dan penerbitan Izin Mendirikan Bangunan. Indikator yang mempengaruhi kinerja tingkat aparatur pelayanan adalah tingkat kesadaran masyarakat didalam melakukan pembangunan di Kabupaten Bulukumba, lokasi dan letak bangunan yang juga membutuhkan tambahan waktu didalam melaksanakan survey lokasi serta alokasi anggaran dan perubahan peraturan perundang undangan yang mengatur tentang pendirian bangunan di Kabupaten Bulukumba.

\section{DAFTAR PUSTAKA}

Adaddanuarta.2014. Kinerja Karyawan Menurut Para Ahli, Nopember 2014 Availabel from: http://adaddanuarta.blogspot.com/2014/11/kinerjakaryawan-menurut-para-ahli.html. Diakses tanggal 19 Agustus 2019

Anwar Prabu Mangkunegara, 2000. Manajemen Sumber Daya Manusia Perusahaan. PT Remaja Rosdakarya. Bandung.

Ariany, R., \& Putera, R. E. (2013). Analisis Kinerja Organisasi Pemerintah dalam Memberikan Pelayanan Publik di Kota Pariaman. MIMBAR, Jurnal Sosial Dan Pembangunan, 29(1), 33. https://doi.org/10.29313/mimbar.v29i1.364 
Azlina, N., \& Amelia, I. (2015). Pengaruh Good Governance Dan Pengendalian Intern Terhadap Kinerja Pemerintah Kabupaten Pelalawan. Jurnal Akuntansi Universitas Jember, 12(2), 32. https://doi.org/10.19184/jauj.v12i2.1409

Buku Informasi Kajian Pemetaan Potensi Daerah Kabupaten Bulukumba Dinas Penanaman Modal dan Pelayanan Terpadu Satu Pintu Kabupaten Bulukumba Tahun 2018

Keputusan Menteri Pendayagunaan Aparatur Negara Nomor 26 Tahun 2004 Tentang Petunjuk Teknis Transparansi dan Akuntabilitas dalam Penyelengaraan Pelayanan Publik.

Keputusan Menteri Pendayagunaan Aparatur Negara Nomor 63/KEP/M.PAN/7/2003 Tentang Pedoman Umum Penyelenggaraan Pelayanan Publik.

Laporan Kegiatan Penanaman Modal Dinas Penanaman Modal dan Pelayanan Terpadu Satu Pintu Kabupaten Bulukumba tahun 2018.

Lukman, L. (2015). Red Tape Dan Perilaku Masyarakat Dalam Pelayanan Izin Usaha Perdagangan Di Kota Makassar. JAKPP : Jurnal Analisis Kebijakan \& Pelayanan Publik, 1(1), 5-16.

Mouw, E. (2013). Kualitas Pelayan Publik di Daerah. Jurnal UNIERA, 2(2), 92-103.

Nubatonis, S. E., Rusmiwari, S., Suwasono, S., Studi, P., Administrasi, I., \& Tunggadewi, U. T. (2014). Implementasi Prinsip-Prinsip Good Governance Dalam Meningkatkan Kinerja Organisasi Pelayanan Publik. JISIP: Jurnal Ilmu Sosial Dan Ilmu Politik, 3(1), 16-20.

S.P,Hasibuan, Malayu. 2013. Manajemen Sumber Daya Manusia. Jakarta: PT Bumi Aksara 